\section{Rozhovor s kolegy a žáky o prof. Evženu Neustupném}

Otázky připravil Martin Kuna a Petr Menšík, rozhovory a úpravy a text připravil Josef Hložek a Petr Menšík.
Acta Fakulty filozofické Západočeské univerzity v Plzni / West Bohemian Review of Social Sciences \& Humanities 2021, Vol. 13 (2), 46-54 DOl: https://doi.org/10.24132/actaff.2021.13.2.4 https://actaff.zcu.cz/ ISSN 2336-6346 4.0 International License.

Prof. PhDr. Evžen Neustupný, CSc. (31. 10. 1933 - 14. 1. 2021) byl jednou z nejvýznamnějších osobností české poválečné a porevoluční archeologie. Jeho práce byla ovlivněna nejen jeho otcem, dlouholetým vedoucím oddělení prehistorie Národního muzea v Praze a profesorem Univerzity Karlovy Jiřím Neustupným, ale také K. Marxem, F. de Saussurem, L. Binfordem, G. W. F. Hegelem a mnoha dalšími osobnostmi různých vědních oborů. V letech 1957-1966 působil Evžen Neustupný v expozituře Archeologického ústavu ČSAV v Mostě, v letech 1990-1993 byl ředitelem Archeologického Ústavu AV ČR v Praze. V roce 1998 založil Katedru archeologie na Západočeské univerzitě v Plzni, kterou dlouhá léta vedl. Jméno Evžena Neustupného je v českém i evropském prostředí spojováno především s archeologickou teorií a metodou. V šedesátých letech 20. století se tento badatel intenzivně zasazoval o rozvoj tehdy začínajícího radiokarbonového datování, výrazně přispěl ke zkvalitnění metody kalibrace dat a obecnému prosazení radiokarbonové chronologie ve střední Evropě, což se odrazilo také ve zpřesnění periodizace mladšího pravěku. V tomto období, nezávisle na evropském vývoji, formuloval v českém prostředí principy procesuálního paradigmatu a $\mathrm{v}$ dalších letech ovlivnil utváření dalších paradigmat. Jeho dlouholetá práce vyústila ve vznik vlastního paradigmatu, který představuje „artefaktová archeologie“. Jeho klíčovými tématy jsou, mimo jiné, otázky spojené s tvưrčí činností člověka, problematika hustoty společenských vztahů v období pravěku a symbolické systémy. Tyto studované oblasti života pravěkých populací výrazně kontrastují s otázkami kladenými v duchu předcházejících paradigmat, mezi které patřila problematika klimatických změn a jejich vlivu na vývoj člověka, otázky migrací či konfliktů. Dalším z výrazných milníků v práci Evžena Neustupného bylo formulování teorie sídleních areálů v 80. letech minulého století, které dodnes významným způsobem ovlivňuje chápání archeologických pramenů. V 90. letech se podílel na vzniku Maltské konvence o ochraně archeologického dědictví Evropy a Evropské asociace archeologů. V průběhu svého působení na Katedře archeologie Západočeské univerzity v Plzni shrnul svou teoretickou práci ve dvou souhrnných monografích o archeologické metodě a teorii. Ve svých posledních pracích se pak zabýval teorií artefaktı̊ a lidského světa. Myšlenky Evžena Neustupného jsou z pohledu mnoha jeho žáků vnímány nejen jako ucelené, ale také neobyčejně inovativní a inspirativní. V současné době je dále rozvíjejí jeho mladší kolegové a žáci nejen na Západočeské univerzitě v Plzni a Archeologickém ústavu AV ČR, Praha, v. v.i., ale také v dalších domácích i evropských vědeckých a výzkumných institucích. Za zásluhy a přínos světové vědě obdržel Evžen Neustupný v roce 2014 cenu Neuron.

$$
* * *
$$

Rozhovor byl proveden s doc. Františkem Gabrielem a doc. Vladimírem Salačem, dále žáky prof. Neustupného, konkrétně dr. Ladislavem Čapkem, dr. Lubošem Chroustovským, dr. Davidem Novákem, Mgr. Janem Pařezem a Mgr. Filipem Prekopem. Všem zmiňovaným byly položeny stejné otázky, na které je možné níže nalézt odpověd'. 


\section{Ladislav Čapek (odborný asistent Katedry archeologie FF ZČU v Plzni)}

1. Které odborné teorie a pojmy spojené s Evženem Neustupným považujete za nejdůležitější v té části archeologie, v níž pracujete?

Principy archeologické teorie a metody propagované E. Neustupným a vycházející obecně z procesuálního paradigmatu se snažím rozvíjet a aplikovat v oblasti archeologie mladšího středověku. Zabývám se především studiem středověké keramiky a dalších movitých artefaktů pocházející z nejrůznějších archeologických kontextů a zjištuji mezi nimi formální, prostorové a behaviorální struktury. Často s využitím formalizovaných analýz a statistických metod. Jejich sociální a ekonomickou interpretaci ověřuji na základě modelů o fungování společnosti. Kromě toho se zabývám také středověkým osídlením a často pracuji se základními pojmy z oblasti teorie sídelních areálů, kterou formuloval počátkem 90. let minulého století právě E. Neustupný.

2. Evžen Neustupný založil novou katedru archeologie a začal systematicky vyučovat až ve věku, kdy jiní odcházejí do důchodu. Učinil tak především proto, aby mohl nové generaci archeologů předat své životní zkušenosti a vyhraněný pohled na obor. Podařilo se mu to? Vidíte jeho odkaz v činnosti KAR dodnes?

E. Neustupný velmi výrazně ovlivnil několik generací archeologů, kteří dnes pracují v řadě archeologických institucí po celé České republice, někteří i v zahraničí. Řada z nich pracuje způsobem, který jim vštípil právě E. Neustupný - tedy metodami založenými na poctivé analýze a syntéze archeologických pramenů. Kromě toho nás pan profesor naučil kritickému myšlení a přistupovat opatrně a kriticky k některým vyřčeným „pravdám“. Bohužel musím konstatovat, že s ochodem pana profesora se jeho odkaz pomalu vytrácí, nebot nikdo z nás nedokáže jasně a srozumitelně předat jeho originální myšlenky mladším generacím, které ho již nezažily. Nicméně zůstalo po něm dílo v podobě dvou stěžejních „modrých knih“, které jsou stále základními učebnicemi k archeologické teorii a metodě na naší katedře.

3. Promítly se názory a teorie Evžena Neustupného do Vašeho osobního odborného směřování a jak?

Téměř pokaždé, když pracuji na nějakém vědeckém článku, byt je z úplně jiného oboru a období, než kterým se pan profesor zabýval, odkazuji na jeho zásadní práce, především Metodu a Teorii archeologie. Je tedy nepochybné, že názory a vědecké uvažování E. Neustupného ovlivnily mé odborné směřování. V současnosti se více zabývám sociální archeologií a zjištuji, že některými „postmoderními“ teoriemi, otázkami a přístupy se již dávno předtím zabýval nebo k nim vyjadřoval ve svých pracích právě pan profesor. V řadě oblastí a témat byl pan profesor „o krok napřed" než někteří současní teoretici vědy.

4. Evžen Neustupný s nadsázkou říkával, že "člověk, o kterém se nevyprávějí historky, žil nadarmo“. Máte $V y$ osobně s jeho osobou spojenou nějakou historku, událost či př́iběh, at́ už vážný, nebo humorný?

S panem profesorem se pojí celá řada historek. Vzpomínám na něj jako na „obávaného“ profesora během mých studentských let, který vždy dokázal výklad odlehčit zajímavým vyprávěním, nebo pověstným anglickým humorem. Pan profesor měl neobyčejný smysl pro humor, který byl vícevýznamový, a ne každý ho ihned pochopil. Více jsem se panem profesorem sblížil až během mého doktorského studia. Z počátku nebyl náš vzájemný vztah „ideální“, nebot místo toho, abych docházel na pravidelné večerní semináře z archeologické teorie pro doktorandy, jsem obrážel jako archeolog-technik terénní archeologické výzkumy po různých místech v Čechách. Po některém 
z mých budoucích kolegů mi pan profesor vzkázal, že jestli „ten Čapek nebude chodit, tak už přiště nemusí přijít". Naštěstí se blížil konec výzkumné sezóny, tak jsem začal navštěvovat jeho semináře pravidelně. Pan profesor se aktivně zajímal o téma mé doktorské práce věnované archeologickým transformacím v prostředí středověkých měst a příležitostně jsme vedli zajímavé a pro mě nesmírně cenné diskuse o výzkumu stratigrafií měst a tellových sídliš̌t. Občas jsem panu profesorovi vypomáhal s nejrůznějšími úkoly spojenými se studijní agendou. Jednou, když se blížil konec jeho působení na katedře, oslovil mě a mého kolegu s neobvyklou prosbou, zda bychom mu nepomohli přestěhovat a převézt jeho osobní věci z kanceláře na katedře do jeho domu v Praze-Troji. Naložili jsme jeho překvapivě skromnou knihovnu a několik osobních věcí (vlastně artefaktů) do katederní dodávky a spolu s panem profesorem jsme vyrazili po dálnici do Prahy. Cestou jsme téměř mlčeli, nebot jsme všichni věděli, že je to vlastně definitivní konec působení pana profesora na katedře. Nicméně až téměř před Prahou jsme zabředli do rozhovoru a pan profesor začal vyprávět nejrůznější příběhy o svých pražských kolezích. Dorazili jsme k jeho vile v Praze-Troji a pomohli mu s věcmi do domu. Pan profesor nás pozval k sobě, abychom si odpočinuli s tím, že nám ale kávu neudělá. V chodbě domu stála dětská tř́kolka, některého z jeho vnoučat. Pobaveně jsme se na pana profesora podívali. Pan profesor konstatoval, že je to přece „ta tř́kolka, na které jezdí do práce do archeologického ústavu“. Chvíli jsme u pana profesora poseděli, a pak se s ním rozloučili a chtěli vyrazit na cestu do Plzně. Pan profesor nás vyprovodil s tím, že nám otevře branku do ulice ze zahrady domu přes elektrické ovládání. Čekali jsme u branky a za chvíli se skutečně ozval bzučivý zvuk otevírání dveří, jenže mě se v tu chvíli nepodařilo branku otevřít a zůstali jsme s kolegou zavřeni uvnitř. Museli jsme znovu zazvonit a požádat, zda by nám neotevřel branku ještě jednou. $\mathrm{V}$ okně jsme pak jen zahlédli pana profesora, jak se nám směje.

\section{František Gabriel (docent a bývalý vedouci Katedry archeologie FF ZČU v Plzni)}

\section{Které odborné teorie a pojmy spojené s Evženem Neustupným považujete za nejdůležitější v té části} archeologie, v níž pracujete?

Je velmi obtížné vyjmout z ucelené teorie a metody některý segment a označit jej za nejdůležitější v části archeologie, ve které pracuji. Teorie pana profesora E. Neustupného je uzavřeným okruhem, kde je každý „bod“ začátkem i koncem oné pomyslné kružnice. Z oněch bodů, z nichž každý lze nadále rozvíjet, mě naposledy zaujal vztah hmotných a písemných historických pramenů. Dotkl se jej v kapitole „Naše“ pojmy a „jejich“ pojmy (E. Neustupný: Metoda archeologie. Plzeň 2007, str. 174-175). Zmínil jej okrajově a z pohledu archeologa, věnujícího se studiu pravěku, tedy doby, která písemné prameny nezná. I přesto se však dotýká mladších období dějin, a autor tak opětovně ukázal na význam jeho práce i pro mladší časové horizonty, zkoumané archeologickou metodou.

2. Evžen Neustupný založil novou katedru archeologie a začal systematicky vyučovat až ve věku, kdy jiní odcházejí do důchodu. Učinil tak především proto, aby mohl nové generaci archeologů předat své životní zkušenosti a vyhraněný pohled na obor. Podařilo se mu to? Vidíte jeho odkaz v činnosti KAR dodnes?

Nevím, zda odkaz pana profesora přežívá dodnes v činnosti KAR. S jistotou mohu pouze potvrdit, že jeho metoda a teorie se ujala v mé práci a v práci mých přátel. U některých jeho kolegů a žáků mám spíše pocit, že jeho teorii a metodu ve své práci neuplatňují. 
3. Promítly se názory a teorie Evžena Neustupného do Vašeho osobního odborného směřování a jak?

Ačkoliv nejsem studentem pana profesora a znal jsem jej pouze z krátkých a spíše úředních jednání, svými články vydanými v češtině moji práci výrazně ovlivnil ve dvou směrech. Jednak mi jejich obsahy umožnily upřesnit postup bádání a správně na něho napojit další dílčí metody při studiu středověkých artefaktů, včetně staveb, a jednak jsem si uspořádal pojmy z oboru.

4. Evžen Neustupný s nadsázkou říkával, že „člověk, o kterém se nevyprávějí historky, žil nadarmo“. Máte $V y$ osobně s jeho osobou spojenou nějakou historku, událost či př́iběh, at́ už vážný, nebo humorný?

I přesto, že s osobou pana profesora nemám spojenou žádnou historku, domnívám se, že nežil nadarmo. Rozhodně poponesl náš obor o značný kus dopředu.

\section{Luboš Chroustovský (odborný asistent Katedry archeologie FF ZČU v Plzni)}

1. Které odborné teorie a pojmy spojené s Evženem Neustupným považujete za nejdůležitější v té části archeologie, v níž pracujete?

Zabývám se archeologickou teorií i v obecné rovině, a tak spatřuji jeho přínos i tam. Zdůraznil bych především jeho schopnost utvořit vlastní teoretický rámec (nejen konkrétní teorii) a vyvodit z něj metodologické důsledky. A to i v nadhledu vůči zažitým vědeckým paradigmatům. Stručně řečeno, uměl nejen (kriticky) přemýšlet a precizně formulovat své předpoklady, otázky i závěry, ale také měl jasno v tom, jak postupovat, abychom naše poznání minulosti prohlubovali opřeni o empirické prameny. Vymyslet teorii není vůbec těžké, ale prokázat, že je relevantní (nikoliv nutně pravdivá), je velice náročná výzva. On se takovým výzvám nevyhýbal.

2. Evžen Neustupný založil novou katedru archeologie a začal systematicky vyučovat až ve věku, kdy jiní odcházejí do důchodu. Učinil tak především proto, aby mohl nové generaci archeologů předat své životní zkušenosti a vyhraněný pohled na obor. Podařilo se mu to? Vidíte jeho odkaz v činnosti KAR dodnes?

Studoval jsem na katedře krátce po jejím založení a musím říci, že nás kromě mladého kolektivu vyučujících zaujal i tehdejší pan docent, byt se zdálo, že svým věkem je nám již vzdálen. Nakonec však získal náš respekt, nebot jsme nad jeho myšlenkami museli opravdu přemýšlet (nevycházely totiž vždy ze selského rozumu a zažitých „pravd“). I v metodách měl před námi neskutečný náskok, vždyt byl schopný si programovat vlastní výpočetní algoritmy, což jsme my mladí, byt okouzlení moderními technologiemi, neuměli. Myslím, že jeho odkaz se nese nejen v konkrétních tématech či metodách, které jsme si osvojili, ale hlavně v jeho kritickém přístupu k dosavadnímu bádání a v hledání nových cest. V obojím nás totiž podporoval.

3. Promítly se názory a teorie Evžena Neustupného do Vašeho osobního odborného směřování a jak?

Seznámil jsem se s jeho př́istupy podrobněji, nebot jsem s jejich pomocí řešil témata diplomové a pak disertační práce, navíc pod jeho vedením. Ale spíše než konkrétní názory, o kterých jsme v našich debatách s nadsázkou říkali, že nejsou „na věčné časy “, to byl jeho kritický postoj opřený o zkušenosti. A vlastně také optimismus, kterým nás obdařoval, když říkal, že se nemáme cítit jako periferie Evropy, ale svým poctivým úsilím můžeme přispět i k velké, světové archeologii. 
4. Evžen Neustupný s nadsázkou říkával, že „člověk, o kterém se nevyprávějí historky, žil nadarmo“. Máte $V_{y}$ osobně s jeho osobou spojenou nějakou historku, událost či př́běh, at’ už vážný, nebo humorný?

Spíše než konkrétní událost bych rád vyzdvihl jeho ochotu debatovat nad čímkoliv. Archeologická témata samozřejmě hrála prim, ale rád se bavil i o politice, o životě, o všem možném. Já osobně jsem je zažíval v přátelském duchu, a tak se mi líbila jeho schopnost svobodného myšlení. A také jeho svérázný humor, blízký např́íklad britskému. Pro humor měl dokonce i vlastní typologii, o níž nám jednou přednášel. A na závěr rád přiznám, že mě nakonec začalo bavit mé usilovné přemýšlení nad tím, zda to, čím uvádí naše setkání či telefonát, není další z jeho šprýmů.

\section{David Novák (Vedoucí Oddělení informačních zdrojů a archeologie krajiny $v$ Archeo- logickém ústavu AVČR, v.v.i. v Praze)}

1. Které odborné teorie a pojmy spojené s Evženem Neustupným považujete za nejdůležitější v té části archeologie, v níž pracujete?

Do české archeologie se jednoznačně nejvíce propsala Neustupného teorie sídelních areálů a celé související pojmosloví. Jelikož jsem po ukončení studia své další působení spojil s Oddělením informačních zdrojů a archeologie krajiny na ARÚ Praha, jedná se svým způsobem o konceptuální východisko mé práce. Již od 90. let vychází evidence dat o terénních archeologických výzkumech v ČR z teorie sídelních areálů a jako taková je základním stavebním kamenem odborné komunikace o archeologických pramenech. Pojmy jako „komponenta“, „sídelní areál“ či „areál aktivity“ dnes užíváme zcela automaticky, byt do českého prostředí pronikly právě v souvislosti s působením E. Neustupného. Podobně formující byly však i práce dotýkající se problematiky archeologických transformací a studie zaměřující se na archeologickou metodu.

2. Evžen Neustupný založil novou katedru archeologie a začal systematicky vyučovat až ve věku, kdy jiní odcházejí do důchodu. Učinil tak především proto, aby mohl nové generaci archeologů předat své životní zkušenosti a vyhraněný pohled na obor. Podařilo se mu to? Vidíte jeho odkaz $v$ činnosti KAR dodnes?

E. Neustupný byl člověkem, který na první místo kladl kritické myšlení a kvalitní metodickou práci. Tím definoval profil KAR a jejích absolventů, kdy hlavním měřítkem byla teoretická a metodická vyspělost a schopnost diskuse, méně již hloubka specifických znalostí o dílčích odborných tématech. KAR tak vždy studentům nabízela prostor pro seberealizaci bez zbytečných bariér definovaných úzce zaměřenými otázkami. Tento př́stup přinášel výhody i nevýhody a v důsledku kladl nároky především na studenty samotné, aby nabízeného prostoru co nejlépe využili. E. Neustupný byl otevřený inovativním př́istupům a mezioborovosti, byl však také zdrcujícím kritikem, kterého nebylo snadné přesvědčit o kvalitách alternativních názorů či teorií. Z KAR však dokázal vytvořit - a to i výběrem svých spolupracovníků a vyučujících - podnětné prostředí s unikátním profilem absolventů, silně zaměřených na teoreticko-metodickou stránku archeologie, inovace a aplikaci moderních metod.

3. Promítly se názory a teorie Evžena Neustupného do Vašeho osobního odborného směřování a jak?

Ano, v mnoha ohledech. Když pomineme již zmíněné pojmosloví a celkové metodické zázemí, za velice podnětné považuji jeho úvahy nad vztahem člověka a artefaktu, nad intencionalitou a nad účelem věcí. Pochopení reciprocity vztahu mezi člověkem a artefaktem je klíčové pro naše uvažování nad vývojem a fungováním lidské společnosti. E. Neustupný v mnohém nepřiznaně 
navazoval na zahraniční diskurs. Bohužel s ním však vědomě odmítal diskutovat a věnoval se raději rozvoji vlastních myšlenek. Přesto jeho práce slouží jako skvělé přemostění od klasické středoevropské kulturně-historické archeologie k moderním přístupům ve světě. Jeho poslední práce bohužel zůstanou nedokončené a lze jen litovat, že dále nerozvine myšlenky prvně nastíněné v jeho posledních knihách, zejména v Teorii archeologie.

4. Evžen Neustupný s nadsázkou říkával, že "člověk, o kterém se nevyprávějí historky, žil nadarmo“. Máte $V_{y}$ osobně s jeho osobou spojenou nějakou historku, událost či příběh, at už vážný, nebo humorný?

Evženův suchý humor byl legendární. Rozpoznat, kdy se vás snaží uvést do rozpaků a kdy své komentáře myslí vážně, bylo mnohdy více než nesnadné. $\mathrm{Z}$ paměti mi vystupuje historka, kdy jsme pro ARÚ sháněli nového pracovníka jako posilu pro tým archivu. V jednom odpoledni před uzávěrkou mi zvoní mobilní telefon a ze sluchátka se ozve známý hlas svým pověstným: „Eeeeehm, pane kolego, tady Neustupný. Já vám volám, protože bych se rád přihlásil do toho výběrového řízení. Četl jsem vaše požadavky a zdá se mi, že bych to mohl splňovat. Kdy mohu nastoupit?" Následně nastalo rozpačité ticho, které si Evžen nepochybně náležitě vychutnal, než mlčení nahradil oboustranný smích a další veselá konverzace. Podobných vtípků každý zažil s E. Neustupným mnoho a všichni se shodují, že se mu v očích objevovala až škodolibá radost vždy, když mohl s něčím podobným vyrukovat. Podobně, jako když své přednášky zpravidla směřoval na čtvrteční brzké ranní hodiny, protože střední večery jsou v Plzni vyhlášené svými hospodskými dýchánky. Proč to dělal, si lze snadno domýšlet.

\section{Jan Pařez (Vedoucí odboru archeologie na Generálním ředitelstvím NPÚ v Praze)}

1. Které odborné teorie a pojmy spojené s Evženem Neustupným považujete za nejdůležitější v té části archeologie, v níž pracujete?

Vzhledem k tomu, že teorie a metoda Evžena Neustupného vycházela ze zásadních světových děl, většina jeho pojmů je stále aktuálních a používaných.

2. Evžen Neustupný založil novou katedru archeologie a začal systematicky vyučovat až ve věku, kdy jiní odcházejí do důchodu. Učinil tak především proto, aby mohl nové generaci archeologů předat své životní zkušenosti a vyhraněný pohled na obor. Podařilo se mu to? Vidíte jeho odkaz v činnosti KAR dodnes?

Řekl bych, že jeho odkaz je patrný na první pohled. Nejen v narativu ostatních kateder archeologie, že se jedná o ty „teoretiky z Plzně“, ale také na př́stupu k tématům, která se na katedře řeší. To vše vychází z jeho pochopení, že archeologie nekončí středověkem a není o „vykopávkách“ bez vědeckých otázek.

3. Promítly se názory a teorie Evžena Neustupného do Vašeho osobního odborného směřování a jak?

Jak jsem psal výše, Metoda archeologie prostupuje snad každou prací, s teorií se protíná má práce podstatně méně a mé zaměření na pozdní novověk v tom hraje zásadní roli. 
4. Evžen Neustupný s nadsázkou říkával, že „člověk, o kterém se nevyprávějí historky, žil nadarmo“. Máte $V_{y}$ osobně s jeho osobou spojenou nějakou historku, událost či př́běh, at’ už vážný, nebo humorný?

Když jsem jako student magisterského studia přicházel na zkoušku, oděn v saku a vestě s „cibulema“ v kapse, sešli jsme se s Evženem Neustupným dole na katedře ve výtahu. Na cestě vzhưru se zadíval na řetízek k hodinkám a požádal mě, zda by se na hodinky nemohl podívat. Při otevření ciferníku se celý rozzářil a prohlásil, že už dlouho neviděl nové hodinky s římskými číslicemi, protože v dnešní době nesmyslně nahradily římské číslovky arabskými a on si na ně nebyl schopen zvyknout. V tu chvíli jsem si uvědomil, že každého z nás formovalo jiné paradigma.

\section{Filip Prekop (Pracovník památkové péče $v$ oddělení specialistů v NPÚ v Lokti)}

1. Které odborné teorie a pojmy spojené s Evženem Neustupným považujete za nejdůležitější v té části archeologie, v níž pracujete?

Určitě je to teorie sídelních areálů a principy archeologické metody.

2. Evžen Neustupný založil novou katedru archeologie a začal systematicky vyučovat až ve věku, kdy jiní odcházejí do důchodu. Učinil tak především proto, aby mohl nové generaci archeologů předat své životní zkušenosti a vyhraněný pohled na obor. Podařilo se mu to? Vidíte jeho odkaz $v$ činnosti KAR dodnes?

At už jako absolvent KAR, tak přímo student pana profesora se cítím být silně ovlivněný jeho přístupem k oboru a jsem určitě vděčný za takovou životní zkušenost. Pozoruji obdobné ovlivnění i u řady mnohem významnějších kolegů, než jsem já, takže si dovolím tvrdit, že ano. Také nevím, co víc měl pro šiřrení svých myšlenek udělat než získat respekt v mezinárodní archeologické komunitě prostřednictvím svých publikací a úspěšně založit novou katedru archeologie. To, že založení katedry se podařilo až v jeho pokročilém věku, mělo jistě vliv na to, že měl již od počátku velmi jasný názor na koncepci jejího směřování. Ano, i dnes spatřuji v některých zaměstnancích KAR pokračovatele jeho odkazu. Velmi jsem obdivoval i to, jaké kolegy si dokázal vybrat, jenž od počátku spoluutvářeli obraz katedry jako opravdu prestižního a inspirativního místa vzdělávání. Je to jistě i závazek pro jeho pokračovatele. Moc bych katedře přál, aby udržela svou vazbu na moderní přístupy i celkovou odvahu bádat v opomíjených koutech oboru.

3. Promítly se názory a teorie Evžena Neustupného do Vašeho osobního odborného směřování a jak?

Stále se snažím, aby se do mé práce jeho přístupy promítaly. Určitě považuji za základ zmíněnou teorii sídelních areálů, která správně brání sklouznutí k př́lišnému formalismu archeologických prací a ponouká k uvědomění si skutečnosti, že za každým artefaktem či lokalitou bychom měli přemýšlet o chování konkrétního člověka v určité živé komunitě v konkrétním geografickém i sociálním prostoru. Rozhodně se také snažím držet archeologické metody jakožto garanta základní kvality a obecné akceptalizace svých prací. Musím zmínit, že rozhodně je inspirativní i jeho odvaha $\mathrm{k}$ řešení archeologických problémů i otevřenosti novým nástrojům, především výpočetní techniky nebo př́rodovědných metod v archeologii. 
4. Evžen Neustupný s nadsázkou říkával, že „člověk, o kterém se nevyprávějí historky, žil nadarmo“. Máte Vy osobně s jeho osobou spojenou nějakou historku, událost či př́běh, at už vážný, nebo humorný?

Rád vzpomínám na jeho vším prostupující svérázný humor, kterým dokázal často překvapit. Domnívám se, že jistý humor byl i ve volbě času jeho přednášek, které rád míval ve čtvrtek v brzkých ranních hodinách, jelikož dobře věděl, že středeční večery byly oblíbeným datem společenských večerů nejen plzeňských studentů archeologie. Rád vzpomínám na jeho ujištění před písemným testem, kdy nám oznámil, že svůj test si zadal sám sobě a odpověděl téměř na všechny otázky správně, takže nemůže být těžký a mnoho dalších.

Vladimír Salač (pracovník pravěkého oddělení ARÚ AV ČR, v.v.i.v Praze, docent Katedry archeologie FF ZČU v Plzni)

1. Které odborné teorie a pojmy spojené s Evženem Neustupným považujete za nejdůležitější v té části archeologie, v níž pracujete?

Protože jsem se dlouho věnoval sídlištní keramice, je pro mě, resp. celé bádání o sídlištích, nejvýznamnější teorie odpadových areálů. Ne snad proto, že ji lze přímo použít při zpracovávání sídliště, ale především proto, že nutí člověka přemýšlet o archeologickém sídlištním materiálu v obecné rovině. V tom ostatně vidím zásadní přínos teoretického bádání E. Neustupného. Jeho brilantní teorie jsou obtížně aplikovatelné, avšak nutí nás podívat se na náš obor z vnějšku, a to velmi obohacuje.

2. Evžen Neustupný založil novou katedru archeologie a začal systematicky vyučovat až ve věku, kdy jiní odcházejí do důchodu. Učinil tak především proto, aby mohl nové generaci archeologů předat své životní zkušenosti a vyhraněný pohled na obor. Podařilo se mu to? Vidíte jeho odkaz $v$ činnosti KAR dodnes?

Při čtení některých studentských prací a textů se začínám obávat, zda se na plzeňské katedře nestává z Evžena Neustupného klasik typu Karla Marxe, jehož práce se kdysi hojně citovaly, aniž by je ovšem kdo hlouběji znal, či dokonce promýšlel.

3. Promítly se názory a teorie Evžena Neustupného do Vašeho osobního odborného směřování a jak?

Nepochybně, již jen proto, že vedl mou kandidátskou, tedy disertační práci. Hodně jsem se od něj naučil o datech, jejich vzniku, analyzování a interpretaci. Vděčný jsem mu také za to, že mě z pozice ředitele ústavu vybral na semestrální pobyt v Německu, byt nebyl spokojen s tím, že jsem si vybral tu „nejkonzervativnější “ univerzitu - v Marburgu. Pokud jde o názory a teorie, tak jsem, s výjimkou metod zpracování a vyhodnocování dat, s E. Neustupným často nesouhlasil a měl jsem odlišné názory, což vedlo k intenzívním diskusím. Nebylo jednoduché s ním nesouhlasit, byl jsem proto nucen o různých tématech, jako prostorová archeologie, malé a velké archeologie, odpadové areály atd., intenzivně přemýšlet a předkládat protiargumenty. Právě při tom jsem se od něj naučil nejvíc. 
4. Evžen Neustupný s nadsázkou říkával, že „člověk, o kterém se nevyprávějí historky, žil nadarmo“. Máte $V_{y}$ osobně s jeho osobou spojenou nějakou historku, událost či př́běh, at’ už vážný, nebo humorný?

E. Neustupný byl mistr suchého humoru, kterým rád překvapoval a bavil, zvláště ty, kteří jej ještě dobře neznali. Krátce po nástupu do ústavu jsem se ho chtěl na něco zeptat ohledně databází, ale v kanceláři jsem ho nezastihl. Při zpáteční cestě jsem jej potkal na schodech a hlásil mu:

- Právě jsem u vás klepal.

- A byl jsem tam?

Jeho odpověd, ostatně, jak jsem posléze zjistil, častěji používaná, se mi líbila, takže když se po čase vyskytla stejná situace, jsem hned hlásil:

- Zrovna jdu od vás. Nejste tam.

- Já vím.

Josef Hložek

Západočeská univerzita v Plzni

hlozek@kar.zcu.cz

Petr Menšík

Západočeská univerzita v Plzni

pmensik@kar.zcu.cz 